\title{
Geomorphological evidence for variations of the North Patagonian Icefield during the Holocene
}

\author{
Neil F. Glasser ${ }^{\mathrm{a}, *}$, Krister N. Jansson ${ }^{\mathrm{a}}$, Stephan Harrison ${ }^{\mathrm{b}}$, Andres Rivera ${ }^{\mathrm{c}}$ \\ ${ }^{a}$ Centre for Glaciology, Institute of Geography and Earth Sciences, University of Wales, Aberystwyth, \\ Ceredigion SY23 3DB, Wales, United Kingdom \\ ${ }^{\mathrm{b}}$ School of Geography and the Environment, University of Oxford, Mansfield Road, Oxford OX1 3TB, England, United Kingdom \\ ${ }^{\mathrm{c}}$ Departamento de Geografia, Universidad de Chile, PO Box 3387, Santiago, Chile and Centro de Estudios Cientificos, Valdivia, Chile
}

\begin{abstract}
Elucidating the timing and extent of former glacier fluctuations is important because of the palaeoclimatic inferences that can be drawn from such studies. Here we present new geomorphological evidence of the patterns of glacier behaviour around the North Patagonian Icefield during the Holocene. Mapping is based on visual interpretation of Landsat 7 ETM+ and Terra ASTER satellite images, including the contemporary glaciers, areas of ice-scoured bedrock, trimlines, glacial lineations, terminal moraines, sandur and fluvial sediments, deltas and ice-contact deposits and alluvial fans. Recession of the icefield is marked by three distinct moraine sets. These moraine sets are interpreted as marking terminal positions related to the "Little Ice Age" and two preceding, but as yet undated, phases of Holocene glacier expansion. Large arcuate terminal moraines in front of three of the western glaciers are interpreted as composite features, reflecting topographic limits to glacier expansion, indicating that caution is required in the interpretation of previous ${ }^{14} \mathrm{C}$ dates obtained from these moraines. There are strong contrasts in the patterns of glacier behaviour between the east and west sides of the North Patagonian Icefield, which cannot be attributed simply to an east/west differential in the rates of change of atmospheric temperature and precipitation. We argue here that glacier response to first-order climate forcing is tempered by second-order controls introduced by regional-scale topographic effects, notably glacier drainage basin extent and area, topographic controls on glacier snout morphology and differences in terminal environment (calving/non-calving) during glacier recession.
\end{abstract}

Keywords: North Patagonian Icefield; Glacial geomorphology; Glacier fluctuations; Little ice age; Holocene; Chile

* Corresponding author. Fax: +44 1970622659.

E-mail address: nfg@aber.ac.uk (N.F. Glasser).

\section{Introduction}

The outlet glaciers of the two Patagonian Icefields (the North and South Patagonian Icefields; Fig. 1) are influenced by the strong climatic gradients across 


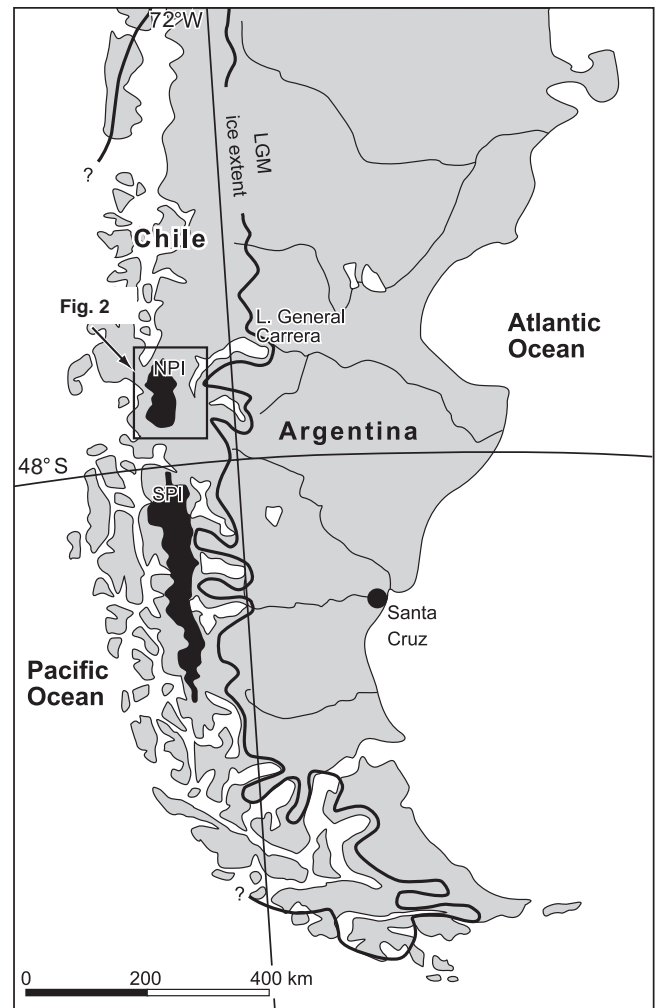

Fig. 1. Southern South America showing the location of the North Patagonian Icefield (NPI), South Patagonian Icefield (SPI) and Last Glacial Maximum (LGM) ice extent (Caldenius, 1932). Inset box shows location of area mapped in detail.

southern South America and are therefore extremely sensitive to climatic change (Aniya and Enomoto, 1986; Kerr and Sugden, 1994; Luckman and Villalba, 2001). The timing of glacier expansion and contraction of these icefields provides valuable information on the forcing mechanisms of climate change (Steig et al., 1998; Denton et al., 1999; Markgraf and Seltzer, 2001), including the latitudinal migration of the precipitation-bearing Southern Westerlies and associated ocean currents (Lamy et al., 2001). The variations experienced by Patagonian glaciers in recent years and the acceleration of the thinning and recession during the last decade are inferred to be a direct response to recorded climatic change in South America (Rignot et al., 2003).

The North Patagonian Icefield $\left(47^{\circ} 00^{\prime} \mathrm{S}, 73^{\circ}\right.$ $39^{\prime} \mathrm{W}$ ) is $120 \mathrm{~km}$ long and $40-60 \mathrm{~km}$ wide, capping the Andean Cordillera between altitudes of 700 and
$2500 \mathrm{~m}$ above sea level (Fig. 1). There are $\sim 70$ outlet glaciers draining the North Patagonian Icefield, with a total ice area (excluding rock outcrops) of $3953 \mathrm{~km}^{2}$ (Rivera et al., in press). The icefield is nourished by the mid-latitude weather systems and is characterised by abundant precipitation, high ablation rates, steep mass-balance gradients and high ice velocities, which, together with sharp local topographic and climatological contrasts, creates a dynamic and temperate glacier system (Warren and Sugden, 1993). Most glaciers of the North Patagonian Icefield are currently receding from their historical maximum positions attained during the "Little Ice Age" between AD 1200 and 1900 (Harrison and Winchester, 2000). However, virtually nothing is known about icefieldwide patterns of Holocene glacier behaviour prior to the "Little Ice Age". Holocene glacier advances of the adjacent South Patagonian Icefield have been assigned to one of three time periods following a 'Mercer-type' chronology, or one of four time periods following an 'Aniya-type' chronology. The 'Mercertype' chronology has glacier advances 4700 to 4200 ${ }^{14} \mathrm{C}$ yr B.P; 2700 to $2000{ }^{14} \mathrm{C}$ yr B.P. and during the "Little Ice Age" (Mercer, 1976). The 'Aniya-type' chronology has glacier advances at $3600{ }^{14} \mathrm{C}$ yr B.P., $2300{ }^{14} \mathrm{C}$ yr B.P., 1600 to $1400{ }^{14} \mathrm{C}$ yr B.P. and during the "Little Ice Age" (Malagnino and Strelin, 1992; Marden and Clapperton, 1995; Aniya, 1995, 1996). Both Mercer- and Aniya-type chronologies are based largely on radiocarbon-dated records, many of which are minimal dates, and from calving glaciers that may react to climate in a non-linear fashion. Indeed, contrasting histories have been obtained for the behaviour of land-terminating glaciers within relatively short distances of each other, possibly explaining the discrepancy between these two chronologies.

Here we report new evidence for icefield-wide patterns of Holocene glacier fluctuations of the North Patagonian Icefield based on the interpretation of remotely sensed data. Our motivation for this study is the need to place the extensive studies of Quaternary stratigraphy (e.g. Rabassa and Clapperton, 1990; Clapperton, 1993; Hajdas et al., 2003), valley-scale geomorphology and glacier fluctuation dating studies (e.g. Clapperton and Sugden, 1988; Winchester and Harrison, 1996; Harrison and Winchester, 1998, 2000; Winchester et al., 2001; Glasser et al., 2002) and the palaeoenvironment (e.g. Heusser and Streeter, 1980; 
Bennett et al., 2000; Massaferro and Brooks, 2002) into a regional geographical context. We use these geomorphological data to elaborate on the factors contributing to the pattern and extent of Holocene glacier fluctuations and to speculate on the timing of these phases of glacier expansion and recession.

\section{Methods}

The glacial geomorphology of the area surrounding the North Patagonian Icefield was mapped by visual interpretation of Terra ASTER (Advanced Spaceborne Thermal Emission and Reflection Radiometer) and Landsat 7 Enhanced Thematic Mapper Plus (ETM+) satellite images. The images were radiometrically and geometrically corrected using the orbital parameters supplied by the USGS, producing a horizontal error on the order of one pixel (15 m for ASTER and $30 \mathrm{~m}$ for Landsat $\mathrm{ETM}+$ ). The data sources used in this study are listed in Table 1, and the features identified on satellite images and the criteria used in their identification are listed in Table 2. The geomorphological mapping was augmented by valley-scale mapping conducted by the authors over a number of field seasons in the following valleys: the San Quintin and San Rafael valleys (Winchester and Harrison, 1996) the Gualas and Reicher valleys (Harrison and Winchester, 1997, 1998), the Arco and Colonia valleys (Harrison and Winchester, 2000), the Nef valley (Winchester et al., 2001), the Soler valley (Glasser and Hambrey, 2002; Glasser et al., 2002) and the Exploradores valley (Harrison et al., 2004). Information on glacier terminal environments and the topographic context of glacier snouts was also recorded (Table 3).

\section{Results: glacial geomorphological mapping}

In this section, we provide a description of the glacial geomorphology of the North Patagonian Icefield and surrounding area (Fig. 2). Figs. 3-6 show typical examples and interpretations of landforms mapped from the satellite images. Table 3 is a summary of the main attributes of the glaciers draining the icefield and their proglacial geomorphology.

\subsection{Contemporary glaciers}

The outlet glaciers typically descend steeply from the icefield, many via icefalls (e.g. Soler, Leones, San Rafael). Glacier surfaces are commonly heavily crevassed (especially at calving termini) with variable amounts of supraglacial material organised into flowparallel medial and lateral moraines (Figs. 4C and 6). Only one of the contemporary western outlet glaciers (San Rafael) is tidewater, terminating in a tidal lagoon. The remainder of the western outlet glaciers terminates in freshwater lakes (e.g. Gualas, Reicher, Benito, HPN2, HPN3, Steffan). An exception to this is the San Quintin Glacier which, until recently (1998), was land terminating but which is now also receding into a freshwater lake (Harrison et al., 2001). The eastern outlet glaciers terminate almost exclusively in freshwater lakes (e.g. Leones, Nef, Colonia, Arenales, Arco, Pared Norte, Fiero), with active lake-calving fronts. The glaciers that are not currently lake-terminating

Table 1

Data sources used in the compilation of the glacial geomorphological map of the area surrounding the North Patagonian Icefield

\begin{tabular}{|c|c|c|c|}
\hline Satellite image & ID number & Date scene acquired & Cloud cover $(\%)$ \\
\hline Terra ASTER ${ }^{\mathrm{a}}$ & AST_L1B.003:2012491016 & $2000 / 5 / 2$ & 6 \\
\hline Terra ASTER ${ }^{\mathrm{a}, \mathrm{b}}$ & AST_L1B.003:2004080855 & $2001 / 9 / 3$ & 6 \\
\hline Terra ASTER ${ }^{\mathrm{a}}$ & AST_L1B.003:2011896528 & $2002 / 1 / 18$ & 5 \\
\hline Terra ASTER ${ }^{\mathrm{a}}$ & AST_L1B.003:2006008908 & $2002 / 2 / 10$ & 25 \\
\hline Terra ASTER $^{\mathrm{a}}$ & AST_L1B.003:2012443150 & $2003 / 2 / 22$ & 7 \\
\hline Landsat $7 \mathrm{ETM}+{ }^{\mathrm{c}}$ & 7232092000107050 & $2001 / 3 / 11$ & 0 \\
\hline Landsat $7 \mathrm{ETM}+{ }^{\mathrm{c}}$ & 7232093000107050 & $2001 / 3 / 11$ & 7 \\
\hline
\end{tabular}

\footnotetext{
${ }^{\text {a }}$ Spatial resolution $15 \mathrm{~m}$ in near-infrared.

b $\sim 50 \%$ thin snow cover.

${ }^{\mathrm{c}}$ Spatial resolution $30 \mathrm{~m}$ in visible and near-infrared and $15 \mathrm{~m}$ in the panchromatic band.
} 
Table 2

Criteria used in identifying landforms from satellite imagery

\begin{tabular}{|c|c|c|c|c|}
\hline \multirow[t]{2}{*}{ Landform/feature } & \multicolumn{2}{|l|}{ Identification criteria } & \multirow[t]{2}{*}{ Possible identification errors } & \multirow[t]{2}{*}{ Glaciological significance } \\
\hline & Morphology & Colour/structure/texture & & \\
\hline $\begin{array}{l}\text { Contemporary } \\
\text { glaciers }\end{array}$ & $\begin{array}{l}\text { Bare ice, snow and debris. } \\
\text { Surface structures } \\
\text { (e.g. crevasses) common. }\end{array}$ & $\begin{array}{l}\text { White to light blue. Surface smooth } \\
\text { to rough. }\end{array}$ & $\begin{array}{l}\text { Minor over-estimate in glacier } \\
\text { extent possible where confused } \\
\text { with snow cover. }\end{array}$ & $\begin{array}{l}\text { Foci for ice discharge from } \\
\text { the contemporary icefield. }\end{array}$ \\
\hline $\begin{array}{l}\text { Ice-scoured } \\
\text { bedrock }\end{array}$ & $\begin{array}{l}\text { Widespread exposures of bare } \\
\text { or lightly vegetated bedrock. } \\
\text { Numerous small lake basins } \\
\text { and open joints visible. }\end{array}$ & $\begin{array}{l}\text { Grey to light pink when vegetation } \\
\text { cover is present. Bedrock structures } \\
\text { and faults often present. Upper } \\
\text { surface often has a rough and } \\
\text { irregular texture. }\end{array}$ & $\begin{array}{l}\text { Possible under-estimate where } \\
\text { bedrock obscured by vegetation } \\
\text { cover. }\end{array}$ & $\begin{array}{l}\text { Evidence for extensive areas } \\
\text { of former glacier ice at its } \\
\text { pressure-melting point. }\end{array}$ \\
\hline Trimlines & $\begin{array}{l}\text { Sub-horizontal lines on valley } \\
\text { sides separating areas of } \\
\text { non-vegetated and vegetated } \\
\text { land or areas covered by } \\
\text { different types of vegetation. }\end{array}$ & $\begin{array}{l}\text { Sharp altitudinal change in surface } \\
\text { colour and texture due to change } \\
\text { in vegetation cover. }\end{array}$ & $\begin{array}{l}\text { Possible, but unlikely, confusion } \\
\text { with other sub-horizontal or } \\
\text { horizontal features such as glacial } \\
\text { lake shorelines. }\end{array}$ & $\begin{array}{l}\text { Former vertical dimensions of } \\
\text { glaciers. }\end{array}$ \\
\hline Glacial lineations & $\begin{array}{l}\text { Parallel features indicating } \\
\text { ice-flow direction. Formed in } \\
\text { bedrock by glacial erosion or } \\
\text { by sediment accumulation. }\end{array}$ & $\begin{array}{l}\text { In bedrock, change in surface } \\
\text { structure compared to surrounding } \\
\text { terrain. In debris, different colour } \\
\text { compared to surrounding terrain } \\
\text { due to change in vegetation cover. }\end{array}$ & $\begin{array}{l}\text { Possible under-estimate in areas } \\
\text { of thin debris cover. Bedrock } \\
\text { landforms may be confused with } \\
\text { bedrock structures in certain } \\
\text { lithologies. }\end{array}$ & $\begin{array}{l}\text { May indicate high former ice } \\
\text { velocities, when highly } \\
\text { attenuated. }\end{array}$ \\
\hline Terminal moraines & $\begin{array}{l}\text { Prominent cross-valley single } \\
\text { or multiple ridges with positive } \\
\text { relief. Linear, curved, sinuous } \\
\text { or saw-toothed in plan. }\end{array}$ & $\begin{array}{l}\text { Shadowing due to change in } \\
\text { relief and change in colour } \\
\text { where moraines are vegetated. }\end{array}$ & $\begin{array}{l}\text { Possible, but unlikely, confusion } \\
\text { with trimlines where moraines } \\
\text { have low relative height. }\end{array}$ & $\begin{array}{l}\text { Moraines mark the former } \\
\text { terminal position of outlet } \\
\text { glaciers. }\end{array}$ \\
\hline $\begin{array}{l}\text { Sandur/fluvial } \\
\text { sediment }\end{array}$ & $\begin{array}{l}\text { Valley floor accumulations of } \\
\text { sediment, commonly dissected } \\
\text { by a braided stream pattern. }\end{array}$ & $\begin{array}{l}\text { Flat, mainly light red areas with } \\
\text { medium grey where there is thin } \\
\text { vegetation cover. Erosional scars } \\
\text { and sharp boundaries with } \\
\text { surrounding terrain. }\end{array}$ & $\begin{array}{l}\text { Possible, but unlikely, confusion } \\
\text { with deltas or ice-contact deposits. }\end{array}$ & $\begin{array}{l}\text { Marks major drainage routes } \\
\text { from contemporary glaciers } \\
\text { and other glacier-fed streams. }\end{array}$ \\
\hline $\begin{array}{l}\text { Delta or ice-contact } \\
\text { deposits }\end{array}$ & $\begin{array}{l}\text { Flat-topped sediment } \\
\text { accumulations above the } \\
\text { present day valley floor, } \\
\text { commonly with a steep } \\
\text { delta front. }\end{array}$ & $\begin{array}{l}\text { Homogeneous surface texture with } \\
\text { flat upper surfaces, erosional scars } \\
\text { and sharp boundaries with } \\
\text { surrounding terrain. }\end{array}$ & $\begin{array}{l}\text { Possible, but unlikely, confusion } \\
\text { with sandur or alluvial fans. }\end{array}$ & $\begin{array}{l}\text { Sediments deposited by streams } \\
\text { draining tributary valleys } \\
\text { onto/against glacier ice in main } \\
\text { valleys. Indicates thickness and } \\
\text { extent of ice in the main valley. }\end{array}$ \\
\hline Alluvial fans & $\begin{array}{l}\text { Sub-horizontal fans on valley } \\
\text { sides. Typically fed by a } \\
\text { meltwater channel or stream. }\end{array}$ & $\begin{array}{l}\text { Fan shaped accumulation with } \\
\text { sharp boundary with surrounding } \\
\text { terrain due to change in vegetation } \\
\text { cover. Pattern of braided streams } \\
\text { on upper surface. }\end{array}$ & $\begin{array}{l}\text { Possible to misinterpret as fossil } \\
\text { delta or ice-contact deposit. }\end{array}$ & $\begin{array}{l}\text { Reworking of unconsolidated } \\
\text { material by contemporary } \\
\text { meltwater channels and streams. }\end{array}$ \\
\hline
\end{tabular}


Table 3

Principle glacier drainage basins and proglacial geomorphology

\begin{tabular}{|c|c|c|c|c|}
\hline Glacier & Location & $\begin{array}{l}\text { Total glacier } \\
\text { area }\left(\mathrm{km}^{2}\right)^{\mathrm{a}}\end{array}$ & Glacier terminal environment ${ }^{\mathrm{b}}$ & $\begin{array}{l}\text { Topographic context of } \\
\text { glacier snout }^{\mathrm{c}}\end{array}$ \\
\hline Grosse & North & 66 & Snout collapsing into shallow proglacial lake & Confined within valley \\
\hline Exploradores & North & 86 & Land-terminating & Confined within valley \\
\hline Fiero & East & 42 & Freshwater calving into moraine-dammed lake & Confined within valley \\
\hline Leones & East & 66 & $\begin{array}{l}\text { Freshwater calving into deep ( } 250 \mathrm{~m} \text { max }) \\
\text { moraine-dammed lake }\end{array}$ & Confined within valley \\
\hline Soler & East & 50 & $\begin{array}{l}\text { Land-terminating, but now grounded in shallow } \\
\text { moraine-dammed lake }\end{array}$ & Confined within valley \\
\hline Nef & East & 127 & $\begin{array}{l}\text { Freshwater calving into deep ( } x \mathrm{~m} \text { max }) \\
\text { moraine-dammed lake }\end{array}$ & Confined within valley \\
\hline Cachet & East & 37 & Freshwater calving into moraine-dammed lake & Confined within valley \\
\hline Colonia & East & 288 & Snout grounded in shallow proglacial lake & Confined within valley \\
\hline Arco & East & 26 & $\begin{array}{l}\text { Land-terminating with deep moraine-dammed } \\
\text { lake in front }\end{array}$ & Confined within valley \\
\hline Pared Norte & South & 80 & Freshwater calving into deep moraine-dammed lake & Confined within valley \\
\hline Pared Sur & South & 32 & $\begin{array}{l}\text { Land-terminating with deep moraine-dammed } \\
\text { lake in front }\end{array}$ & Confined within valley \\
\hline HPN-4 & South & 65 & Land-terminating & Confined within valley \\
\hline Steffen & South & 428 & Freshwater calving into shallow moraine-dammed lake & Unconfined \\
\hline Acodado & West & 269 & $\begin{array}{l}\text { Three termini: two freshwater calving, one } \\
\text { land-terminating }\end{array}$ & Unconfined \\
\hline HPN-1 & West & 153 & Land-terminating & Confined within valley \\
\hline Benito & West & 161 & Freshwater calving into moraine-dammed lake & Unconfined \\
\hline Fraenkel & West & 31 & Freshwater calving into lake & Confined within valley \\
\hline San Quintin & West & 790 & Freshwater calving into moraine-dammed lake & Unconfined \\
\hline San Rafael & West & 722 & Tidewater calving into deep ( $200 \mathrm{~m}$ max) tidal lagoon & Unconfined \\
\hline Gualas & West & 119 & Freshwater calving into shallow moraine-dammed lake & Confined within valley \\
\hline Reicher & West & 72 & Freshwater calving into deep moraine-dammed lake & Confined within valley \\
\hline
\end{tabular}

${ }^{a}$ Glacier data are taken from Rivera et al. (in press) for glaciers with a drainage basin area $>25 \mathrm{~km}^{2}$.

${ }^{\mathrm{b}}$ Glacier terminal environment was determined from ASTER imagery. Qualitative lake depths (shallow/deep) are based on the presence/ absence of sediment bodies in the lakes and values reported in the literature.

c Topographic context is based on whether the current glacier terminus is located within a steep, narrow bedrock valley or otherwise.

(e.g. Colonia and Arco) previously terminated in lakes during the latter part of the nineteenth century. In addition, several outlet glaciers (e.g. Soler, Exploradores) appear to be receding into shallow basins that, as recession continues, are rapidly forming lakes around the glacier snout. A number of glaciers currently retain ice-dammed lakes in their upper regions (e.g. San Quintin, Steffan, Benito, HPN3). East of the icefield, the higher summits contain independent snowfields and satellite glaciers. These are generally steep, topographically constrained cirque glaciers (Fig. 2).

\subsection{Ice-scoured bedrock}

Large tracts of ice-scoured bedrock are visible on the satellite imagery (Figs. 2 and 4A,D) and these are concentrated along the major ice discharge routes (i.e. along valley axes). Ice-scoured bedrock is generally absent on the higher ground (interfluves) between the major valleys. In the southeastern part of the study area, ice-scoured bedrock is associated with glacial lineations and streamlined landforms. The presence of large areas of icescoured bedrock along valley axes and its absence on interfluves indicate sustained vigorous ice flow by temperate glaciers along the main valley routes, equivalent to the selective linear erosion of Sugden and John (1976). Since patches of ice-scoured bedrock are present in the valleys at considerable distances from the contemporary glaciers (up to the outer limits of the mapped area), it is probable that much of this bedrock erosion was associated with 


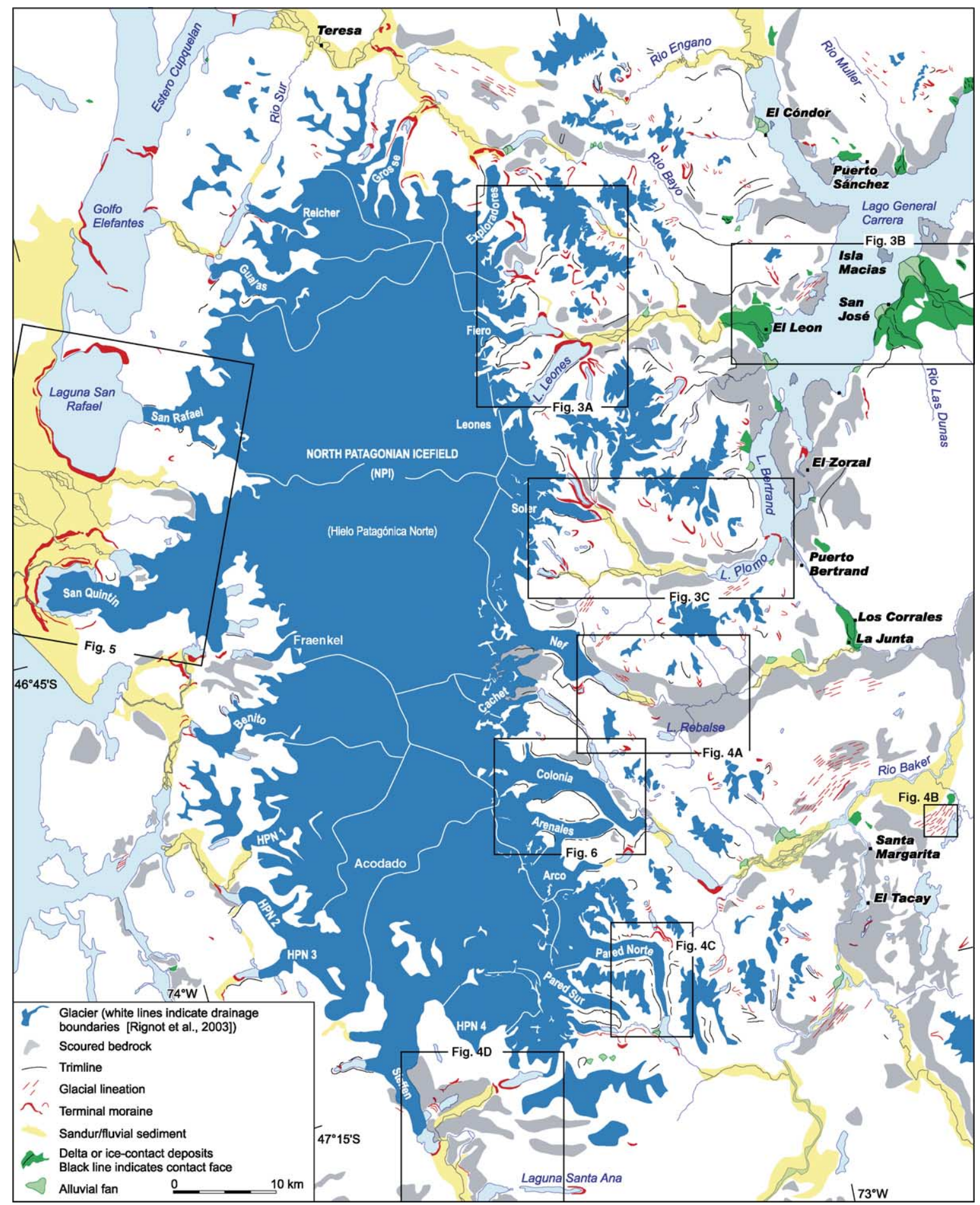

Fig. 2. Glacial geomorphological map of the North Patagonian Icefield compiled from visual interpretation of Terra ASTER (Advanced Spaceborne Thermal Emission and Reflection Radiometer) and Landsat 7 Enhanced Thematic Mapper Plus (ETM+) satellite images. Inset boxes show locations of Figs. 3A-C, 4A-D, 5 and 6. 

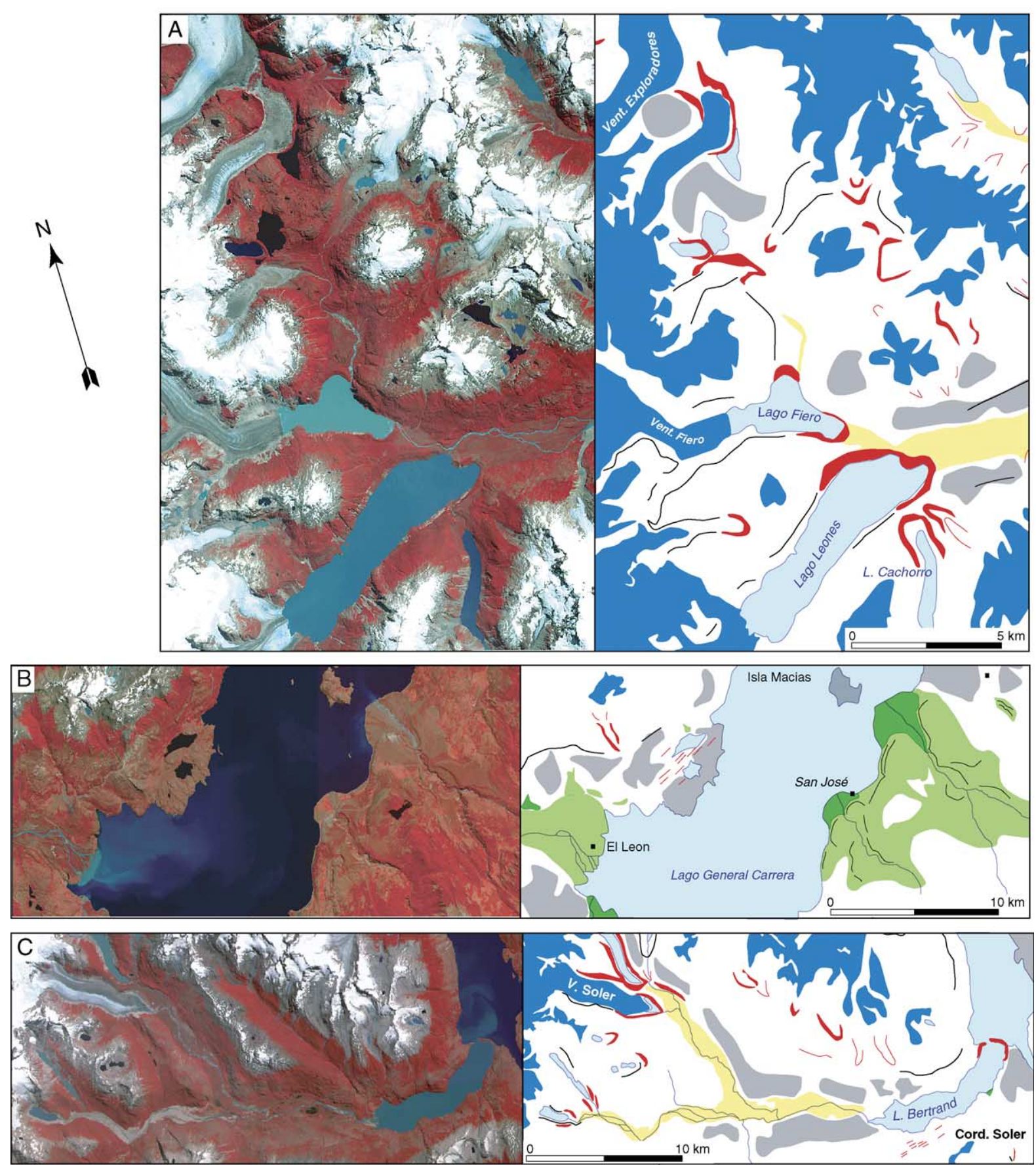

Fig. 3. Landforms on the north and eastern side of the North Patagonian Icefield: Terra ASTER subscenes (bands 1, 2, and 3N) and interpretation showing the major geomorphological features of the area. (A) Glaciers Exploradores, Fiero, Leones and satellite glaciers. The icefield glaciers have large terminal moraines enclosing proglacial lakes and trimlines, whilst the satellite glaciers have smaller terminal moraines. (B) Part of Lago General Carrera showing large deltas and ice-contact deposits at the mouths of tributary glaciers. The deltas and icecontact deposits are being incised by contemporary streams to produce alluvial fans. (C) Rio Soler showing the contemporary glacier, extensive sandur and the large arcuate moraine in Lago Bertrand. For location and key to geomorphological features, see Fig. 2. 

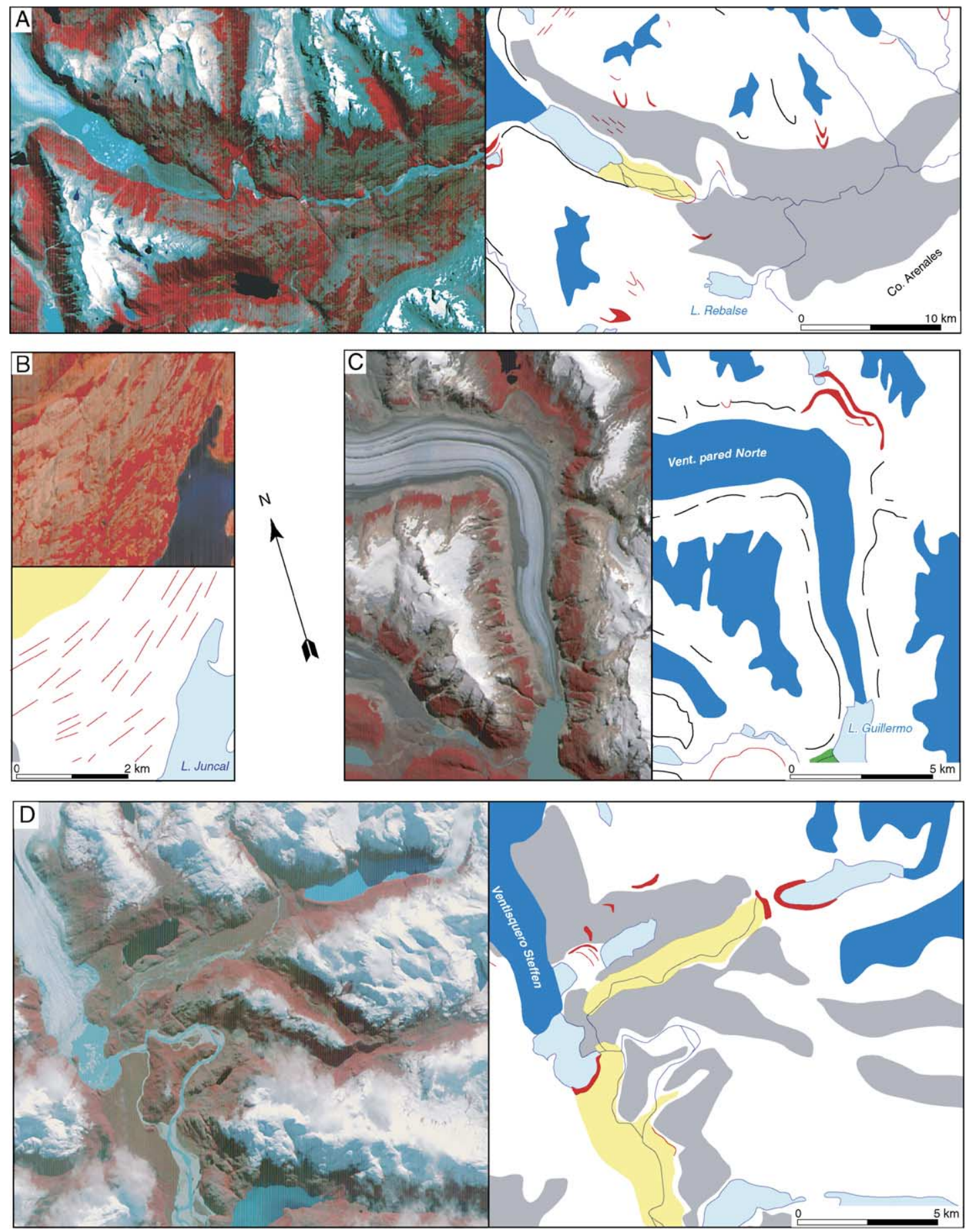

Fig. 4. Terra ASTER subscenes (bands 1, 2 and 3N) and interpretation showing the major geomorphological features on the south and east side of the North Patagonian Icefield. (A) The terminus of Glacier Nef showing ice-scoured bedrock and Rio Nef. (B) Glacial lineations to the north of Lago Juncal. (C) Glacier Pared Norte with well developed trimlines and lateral moraines. (D) Glacier Steffan (top left of image) and unnamed glacier (top right of image) with arcuate terminal moraines enclosing proglacial lakes, ice-scoured bedrock in the valleys and extensive sandur. For location and key to geomorphological features, see Fig. 2. 


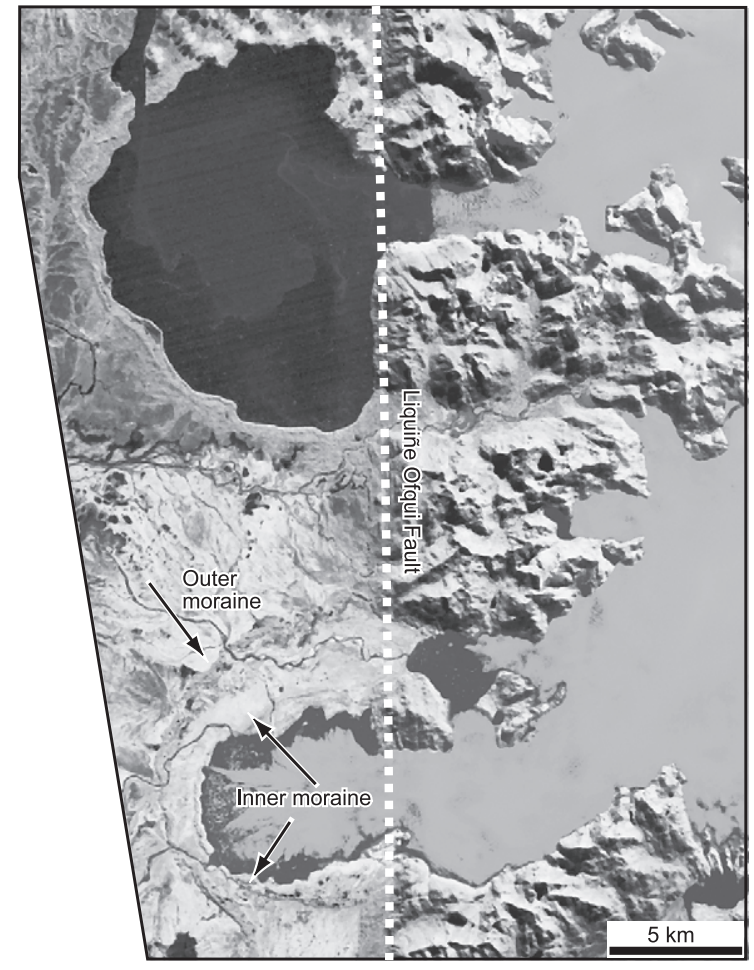

Fig. 5. Landsat ETM+ subscene showing arcuate terminal moraines and sandar marking the limits of large former piedmont lobes on the west side of the North Patagonian Icefield. For location and key to geomorphological features, see Fig. 2.

the Last Glacial Maximum ice masses (Glasser and Jansson, 2005).

\subsection{Trimlines}

Sub-horizontal trimlines are present along the margins of many of the contemporary glaciers, especially those on the eastern side of the icefield (Figs. 2 and 4C). Trimlines can be traced along the glacier margins for considerable distances (e.g. 10 $\mathrm{km}$ at Lago Leones) before merging with welldeveloped terminal and lateral moraines (Fig. 3A). The trimlines mark the vertical extent of former glaciers and are useful in making glaciological reconstructions. Dendrochronology and lichenometry indicate that most are very recent in age, dating from the Little Ice Age, around AD 1700-1900 (e.g. Harrison and Winchester, 1998), although Aniya and Naruse (1999) dated similar trimlines in the Soler valley to ca. AD 700 .

\subsection{Glacial lineations}

At several locations in the study area, streamlined landforms/lineations occur, and are defined by sharp lateral boundaries (Fig. 2). These landforms, commonly associated with scoured bedrock, are generally aligned along major ice discharge routes (i.e. along valleys) such as those present in the Rio de la Colonia/ Rio Baker valley. The occurrence of glacially streamlined landforms in areas of thin debris cover or the absence of soil indicates that these features are mainly drumlinoids and/or grooved bedrock (for example east of Cordon Cabeza de León). Regular drumlins and flutes are present for example north of Laguna Juncal (Fig. 4B). These features are typically between $500 \mathrm{~m}$ and $2 \mathrm{~km}$ in length and approximately $100 \mathrm{~m}$ wide. The lineations east of the North Patagonian Icefield are attenuated lineations. Streamlined landforms are more common to the east of the North Patagonian Icefield and are notably lacking from the areas surrounding the western outlet glaciers (Fig. 2).

\subsection{Terminal moraines}

Well-developed terminal moraines mark the former extent of many of the outlet glaciers of the icefield and its satellite glaciers (Fig. 2). Three moraine sets are recognised, defined by their relative size, morphology and distance from the contemporary icefield. All three moraine sets are located within the established Last Glacial Maximum limits of the North Patagonian Icefield (Morner and Sylwan, 1989; Wenzens, 1999; Strelin and Malagnino, 2000; Kaplan et al., 2004) (Fig. 1A). The first set includes the small moraines that lie within $5 \mathrm{~km}$ of virtually all contemporary glacier snouts, marking post-"Little Ice Age" glacier recession (Winchester and Harrison, 1996; Winchester et al., 2001; Harrison and Winchester, 1998, 2000) (Fig. 3A). The second set includes moraines that lie 5 to $15 \mathrm{~km}$ from the contemporary glacier snouts. This set includes three large arcuate terminal moraines that mark former terminal positions of the San Quintin, San Rafael, Gualas and Reicher Glaciers (Fig. 5). Possible east side equivalents are the large moraines that dam the proglacial lakes at Leones, Nef, Colonia and Pared Norte Glaciers (Fig. 2). The third set includes moraines and associated ice-contact deposits over 15 


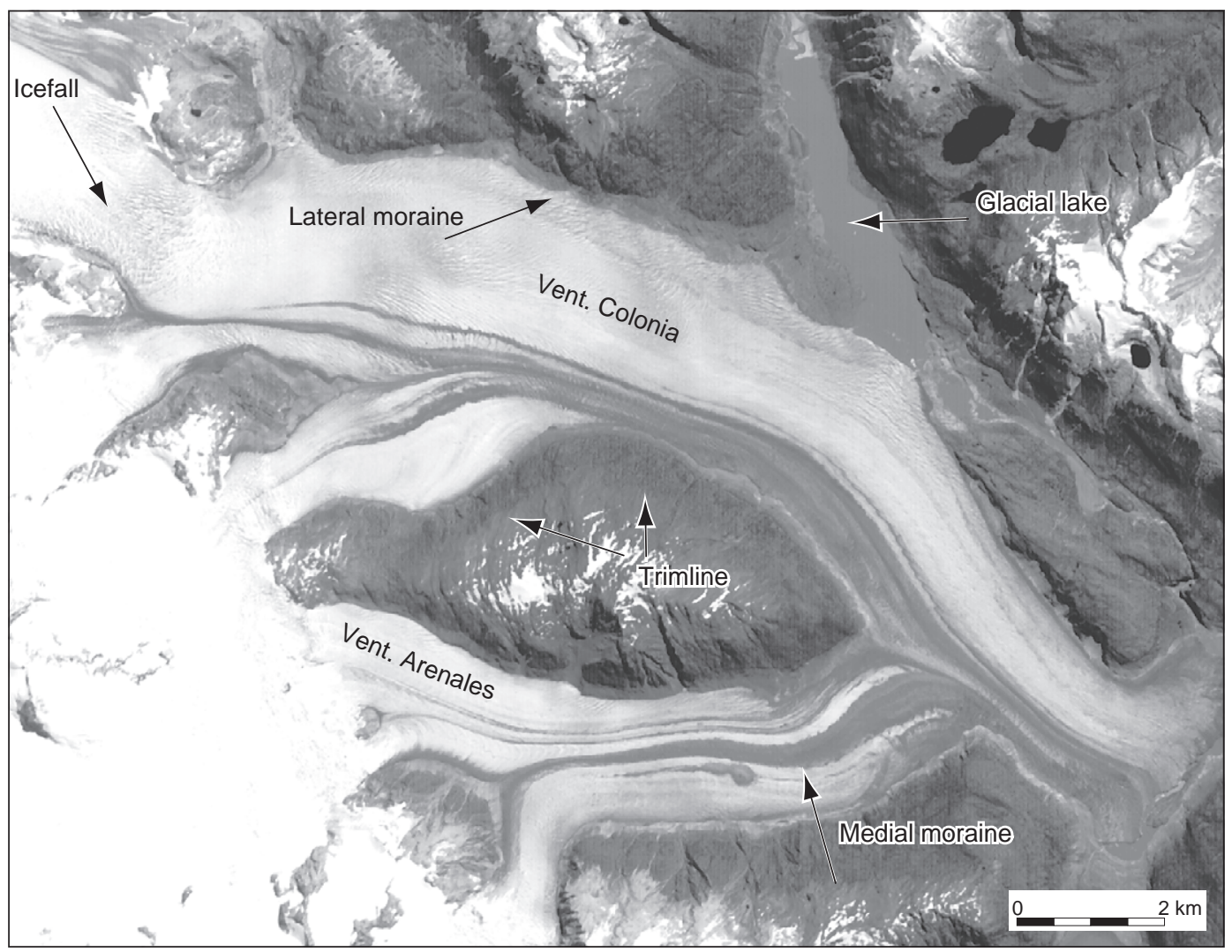

Fig. 6. Glaciers Arenales and Colonia showing glacier surface features and surrounding geomorphology. For location, see Fig. 2.

$\mathrm{km}$ from the contemporary glacier snouts. The largest of these is the terminal moraine in the Rio Soler between Lago Plomo and Lago Bertrand (Fig. 3C).

\subsection{Sandur/fluvial sediment}

Large sandur (outwash plains) are present on the valley floors in front of all the contemporary glaciers (e.g. Leones, Soler, Nef, Colonia), either draining the glaciers directly or buffered from the glaciers by proglacial lakes (Figs. 3A,C and 4D). On the west side of the icefield, sandur are present only outside the large arcuate moraine systems (Fig. 5). Here, they cover broad extensive areas and are less confined than the eastern sandur.

\subsection{Delta and ice-contact deposits}

The delta and ice-contact deposits identified in this study are large sediment accumulations at the con- fluences of tributary valleys and the eastward-trending main valleys (Fig. 2). Their flat upper surfaces and steep outer faces indicate that these delta and icecontact deposits were built out against glacier ice occupying lower ground in the main valleys. The delta and ice-contact deposits therefore mark the former vertical extent of the glaciers in these main valleys. Particularly well-developed examples occur at the mouth of the Leones Valley where it joins Lago General Carrera (Fig. 3B) and in the Rio Nef. By contrast, these features are absent from the west side of the icefield.

\subsection{Alluvial fans}

Alluvial fans identified in this study are large sediment accumulations at the mouths of the valleys to the east of the icefield (Fig. 2). In some instances (e.g. around Lago General Carrera; Fig. 3B), the alluvial fans appear to be reworking older delta and 
ice-contact deposits. These alluvial fans are interpreted as contemporary fluvial features.

\section{Discussion}

\subsection{Moraine sets and correlation}

The moraine sets around the North Patagonian Icefield and their association with areas of ice-scoured bedrock, trimlines, glacial lineations, sandur and fluvial sediments, deltas and ice-contact deposits and alluvial fans can be used to reconstruct the extent of the North Patagonian Icefield at three time intervals during the Holocene (Fig. 7).

\subsubsection{Moraine set 1}

The first moraine set and associated trimlines, closest to the contemporary glaciers, have been dated by lichenometry and dendrochronology to the "Little Ice Age" (Winchester and Harrison, 1996; Winchester et al., 2001; Harrison and Winchester, 1998, 2000). Glacier advances on the west side of the North Patagonian Icefield were greatest at San Quintin

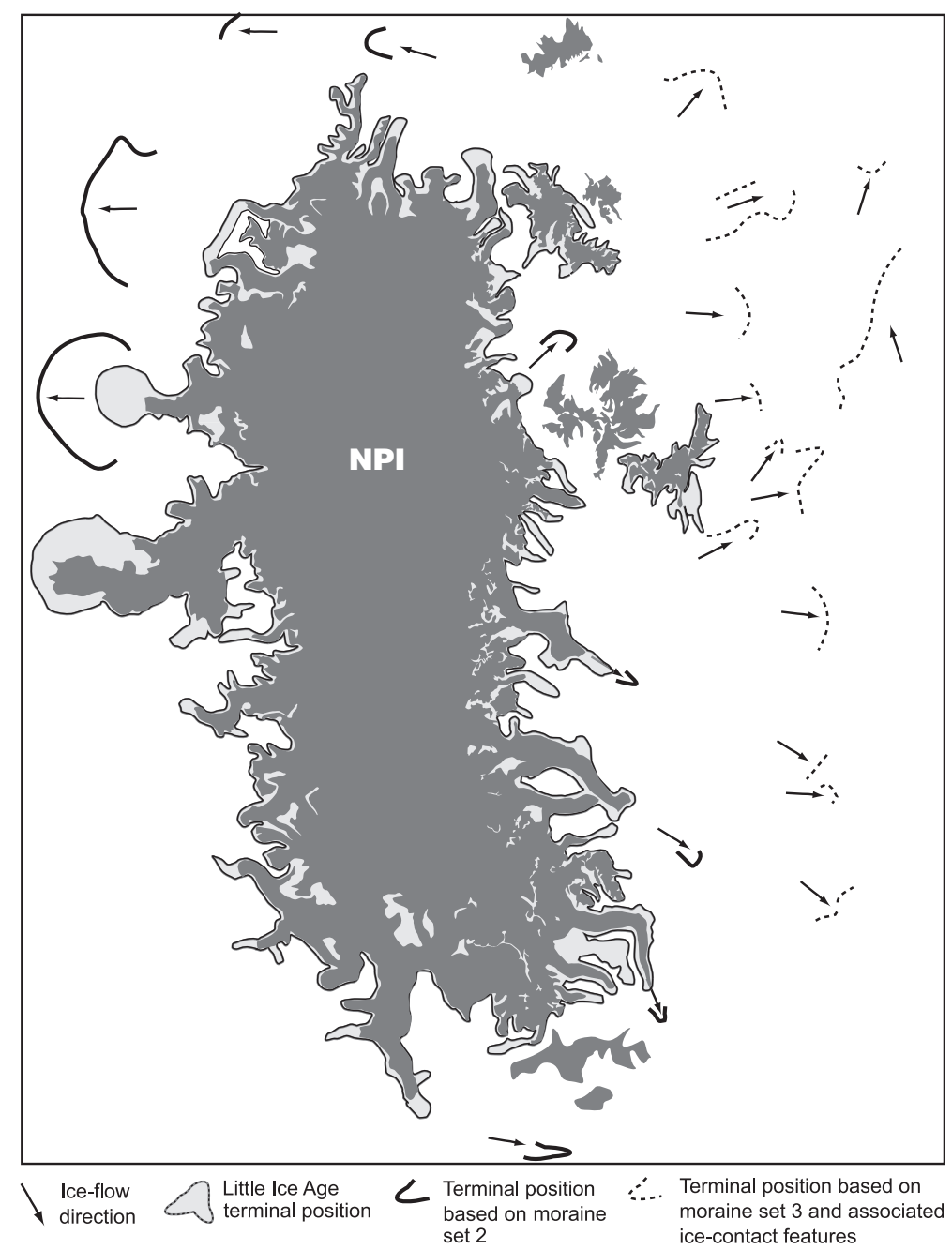

Fig. 7. Holocene recessional history of the North Patagonian Icefield at three time intervals. "Little Ice Age" terminal positions are based on historical records, aerial photography and geomorphic surfaces dated by lichenometry and dendrochronology (Winchester and Harrison, 1996; Winchester et al., 2001; Harrison and Winchester, 1998, 2000). 
Glacier, where an arcuate moraine (labelled outer moraine on Fig. 5) marks the presence of a large piedmont lobe, but advances were more restricted at San Rafael, Gualas and Reicher Glaciers. Historical records (e.g. Simpson, 1875) indicate that the terminus of San Rafael Glacier failed to cross the Laguna San Rafael during the "Little Ice Age". The "Little Ice Age" advance of San Rafael Glacier was probably restricted because rapid iceberg calving accompanied its advance into the deep water of the Laguna San Rafael (Warren, 1993). The Reicher and Gualas Glaciers were probably confluent at this time but their termini ended in overdeepened lakes and thus did not extend far down the Gualas valley (Harrison and Winchester, 1998). In contrast, the land-terminating San Quintin Glacier was not affected by calving during the "Little Ice Age". Deep freshwater terminal lakes are also present on the east side of the North Patagonian Icefield, and again the potential for rapid iceberg calving restricted the "Little Ice Age" advances of many of these glaciers.

\subsubsection{Moraine set 2}

The second moraine set includes (i) arcuate terminal moraines 5 to $15 \mathrm{~km}$ from the contemporary glacier snouts at San Rafael, Gualas and Reicher Glaciers to the west of the North Patagonian Icefield, marking the position of former piedmont lobes and (ii) moraines damming the proglacial lakes of Leones, Colonia and Pared Norte Glaciers to the east of the North Patagonian Icefield. The San Rafael moraine has traditionally been considered to mark the onset of Neoglaciation in the southern Andes around $5000{ }^{14} \mathrm{C}$ yr B.P. (e.g. Clapperton and Sugden, 1988; Porter, 2000; Heusser, 2002). However, the age of the San Rafael moraine is debated; ${ }^{14} \mathrm{C}$ dates for this moraine range from $6850 \pm 200{ }^{14} \mathrm{C}$ yr B.P. (Heusser, 1960 ) to $3600{ }^{14} \mathrm{C}$ yr B.P. (Muller, 1960). Dating of moraines in front of these piedmont lobes is problematic because it is possible that these moraines are in fact composite features, marking terminal positions occupied more than once during the Holocene. Thus, the different age estimates for the San Rafael moraines may be the result of the reworking of older sediments during more than one advance. If such reworking took place, it is possible that these moraines are actually much younger than their apparent ${ }^{14} \mathrm{C}$-dated age.

\subsubsection{Moraine set 3}

On the east side of the North Patagonian Icefield, over $15 \mathrm{~km}$ from the contemporary glacier snouts, is a third moraine set and associated ice-contact deposits interpreted to be older than moraine sets 1 and 2 (Fig. 7). There are no documented west side equivalents of these moraines. The age of these landforms is uncertain, but since they lie within the established Last Glacial Maximum limits of the North Patagonian Icefield (Morner and Sylwan, 1989; Wenzens, 1999; Strelin and Malagnino, 2000), we speculate that they may represent an early Holocene or Late-glacial phase of glacier expansion.

\subsection{Possible explanations for Holocene glacier behaviour}

The distribution of the three moraine sets indicates clear differences in the response styles of the outlet glaciers of the North Patagonian Icefield to imposed Holocene climate change and its consequent changes in glacier mass balance. For example, on the west of the North Patagonian Icefield, moraine set 2 is marked by large arcuate terminal moraines indicating the position of former piedmont lobes and sandar 5 to 15 $\mathrm{km}$ from the contemporary glacier snouts, whilst expansion of the eastern glaciers is marked by smaller within-valley terminal moraines. There are 4 possible explanations for these east/west contrasts in Holocene glacier behaviour.

I. Changes in Holocene atmospheric temperature and precipitation were not uniformly distributed, causing glaciers to the east and west of the icefield to react differently to changes in climate and glacier mass balance (Warren and Sugden, 1993). However, the marked synchroneity in recession of outlet glaciers on both sides of the icefield during the "Little Ice Age" (Fig. 2) suggests that this differential climate forcing did not operate during historical times.

II. The terminal moraines marking the former position of large piedmont lobes at San Quintin, San Rafael, Gualas and Reicher Glaciers are a function of the relatively large drainage basins of these glaciers and therefore reflect the greater overall mass fluxes of these western glaciers. Two western glaciers, the San Quintin and San 
Rafael Glaciers together drain $\sim 38 \%$ of the area of the entire contemporary North Patagonian Icefield $\left(1512 \mathrm{~km}^{2}\right.$ of a total area of $3953 \mathrm{~km}^{2}$; Table 3).

III. Holocene glacier response is closely related to changes in terminal environment (e.g. calving/ non-calving and temporal transitions between these two states) during glacier recession (Warren, 1994; Warren and Aniya, 1999). The potential for western glaciers to form tidewater termini (e.g. San Rafael and Gualas) and eastern glaciers to form lake-calving termini (e.g. Leones, Nef, Colonia, Pared Norte) means that fluctuations do not always accurately reflect regional climatic events. Differences in the behaviour of neighbouring glaciers (e.g. San Quintin, San Rafael, Gualas and Reicher) can also be explained by their contrasting terminal environments. For example, the land-terminating San Quintin Glacier sustained a larger "Little Ice Age" advance than the adjacent San Rafael Glacier because advances of the latter glacier were inhibited by rapid tidewater calving into water depths locally in excess of $200 \mathrm{~m}$ (Warren, 1993).

IV. There are strong topographic controls on glacier extension. On the west of the North Patagonian Icefield, the Liquiñe Ofqui mega fault (marked on Fig. 5) and its seaward topographic depression allow lateral expansion of advancing glaciers to form low-gradient piedmont lobes, whereas to the east of the North Patagonian Icefield, the narrow valleys confine alpine-type glaciers (Fig. 2). Thus, there are internal glaciological thresholds, most notably the high ablation rates associated with these western piedmont lobes, which limit expansion of the glaciers and which may cause these glaciers to re-occupy the same position during successive advances.

\section{Conclusions}

Areas of ice-scoured bedrock, trimlines, glacial lineations, terminal moraines, sandur and fluvial sediments, deltas and ice-contact deposits and alluvial fans around the North Patagonian Icefield indicate the presence of three distinct glacier limits, inferred to be of different ages. Terminal moraines and trimlines closest to the contemporary glacier snouts have been dated to the "Little Ice Age" but, in the absence of dating control, absolute ages cannot be assigned to the two phases of glacier extension. This overall pattern is comparable to that of the adjacent South Patagonian Icefield, where pre-"Little Ice Age" advances have been dated to $3600{ }^{14} \mathrm{C}$ yr B.P., $2300{ }^{14} \mathrm{C}$ yr B.P. and 1600 to $1400{ }^{14} \mathrm{C}$ yr B.P. Strong contrasts exist in the geomorphology and inferred patterns of glacier behaviour between the east and west sides of the North Patagonian Icefield, which implies that glacier response to first-order climate change is moderated by second-order controls. These second-order controls include glacier drainage basin area, topographic limits on glacier snout morphology and differences in terminal environment (calving/non-calving) during glacier recession.

\section{Acknowledgements}

This work was funded by grants from the Royal Geographical Society (grant RGS 03/02) and the UK Natural Environment Research Council (grant NER/ $\mathrm{B} / \mathrm{S} / 2002 / 00282$ ). GLIMS and the USGS gave unrestricted access to ASTER and LANDSAT ETM+ images. Krister Jansson acknowledges funding from the Royal Physiographic Society in Lund. We thank Raleigh International for field logistical support in Chile over a number of years.

\section{References}

Aniya, M., 1995. Holocene glacial chronology in Patagonia: Tyndall and Upsala Glaciers. Arctic and Alpine Research 27, $311-322$.

Aniya, M., 1996. Holocene variations of Ameghino Glacier, southern Patagonia. The Holocene 6, 247-252.

Aniya, M., Enomoto, H., 1986. Glacier variations and their causes in the Northern Patagonian Icefield, Chile since 1944. Arctic and Alpine Research 18, 307-316.

Aniya, M., Naruse, R., 1999. Late-Holocene glacial advances at Glaciar Soler, Hielo Patagonico Norte, South America. Transactions of the Japanese Geomorphological Union 20, 69-83.

Bennett, K.D., Haberle, S.G., Lumley, S.H., 2000. The last glacialHolocene transition in Southern Chile. Science 290, 325-328.

Caldenius, C.C., 1932. Las glaciaciones cuaternarios en la Patagonia y Tierra del Fuego. Geografiska Annaler 14, 1-164 (English summary, 144-157). 
Clapperton, C.M., 1993. Quaternary Geology and Geomorphology of South America. Elsevier, Amsterdam. 779 pp.

Clapperton, C.M., Sugden, D.E., 1988. Holocene glacier fluctuations in South America and Antarctica. Quaternary Science Reviews 7, 185-198.

Denton, G.H., Heusser, C.J., Lowell, T.V., Moreno, P.I., Andersen, B.G., Heusser, L.E., Schluchter, C., Marchant, D.R., 1999. Interhemispheric linkage of paleoclimate during the last glaciation. Geografiska Annaler 81A, 107-153.

Glasser, N.F., Hambrey, M.J., 2002. Sedimentary facies and landform genesis at a temperate outlet glacier: Soler Glacier, North Patagonian Icefield. Sedimentology 49, 43-64.

Glasser, N.F., Jansson, K., 2005. Fast-flowing outlet glaciers of the Last Glacial Maximum Patagonian Icefield. Quaternary Research 63, 206-211.

Glasser, N.F., Hambrey, M.J., Aniya, M., 2002. An advance of Soler Glacier, North Patagonian Icefield at c. AD 1222-1342. The Holocene 12, 113-120.

Hajdas, I., Bonani, G., Moreno, P.I., Ariztegui, D., 2003. Precise radiocarbon dating of Late-Glacial cooling in mid-latitude South America. Quaternary Research 59, 70-78.

Harrison, S., Winchester, V., 1997. Age and nature of paraglacial debris cones along the margins of the San Rafael glacier, Chilean Patagonia. The Holocene 7, 481-487.

Harrison, S., Winchester, V., 1998. Historical fluctuations of the Gualas and Reicher Glaciers, North Patagonian Icefield, Chile. The Holocene 8, 481-485.

Harrison, S., Winchester, V., 2000. Nineteenth- and twentiethcentury glacier fluctuations and climatic implications in the Arco and Colonia Valleys, Hielo Patagonica Norte, Chile. Arctic Antarctic and Alpine Research 32, 55-63.

Harrison, S., Warren, C.R., Winchester, V., Aniya, M., 2001. Onset of rapid calving and retreat of Glaciar San Quintin, Hielo Patagónico Norte, southern Chile. Polar Geography 25, 54-61.

Harrison, S., Glasser, N.F., Aniya, M., 2004. Morphostratigraphy of moraines in the Lago Tranquilo area, Chilean Patagonia. Bulletin of Glaciological Research 21, 37-43.

Heusser, C.J., 1960. Late-Pleistocene environments of the Laguna San Rafael area, Chile. Geographical Review 50, 555-577.

Heusser, C.J., 2002. On glaciation of the southern Andes with special reference to the Península de Taitao and adjacent Andean cordillera $\left(\sim 46^{\circ} 30^{\prime} \mathrm{S}\right)$. Journal of South American Earth Sciences $15,577-589$.

Heusser, C.J., Streeter, S.S., 1980. A temperature and precipitation record of the past 16,000 years in southern Chile. Science 210, $1345-1347$.

Kaplan, M.R., Ackert, R.P., Singer, B.S., Douglass, D.C., Kurz, M.D., 2004. Cosmogenic nuclide chronology of millennial-scale glacial advances during O-isotope stage 2 in Patagonia. Geological Society of America Bulletin 116, 308-321.

Kerr, A.R., Sugden, D.E., 1994. The sensitivity of the southern Chilean snowline to climatic change. Climate Change 28, $255-272$.

Lamy, F., Hebbeln, D., Röhl, U., Wefer, G., 2001. Holocene rainfall variability in southern Chile: a marine record of latitudinal shifts of the South Westerlies. Earth Planetary Science Letters 185, $369-382$.
Luckman, B.H., Villalba, R., 2001. Assessing the synchroneity of glacier fluctuations in the western cordillera of the Americas during the last millennium. In: Markgraf, V. (Ed.), Interhemispheric Climate Linkages. Academic Press, London, pp. 119-140.

Malagnino, E., Strelin, J., 1992. Variations of Upsala Glacier in southern Patagonia since the late Holocene to the present. In: Naruse, R., Aniya, M. (Eds.), Glaciological Researches in Patagonia. Japanese Society of Snow and Ice, pp. 61-85.

Marden, C.J., Clapperton, C.M., 1995. Fluctuations of the Southern Patagonian icefield during the last glaciation and The Holocene. Journal of Quaternary Science 10, 197-209.

Markgraf, V., Seltzer, G.O., 2001. Pole-equator-pole paleoclimates of the Americas integration: toward the big picture. In: Markgraf, V. (Ed.), Interhemispheric Climate Linkages. Academic Press, London, pp. 433-442.

Massaferro, J., Brooks, S.J., 2002. Response of chironomids to Late Quaternary environmental change in the Taitao Peninsula, southern Chile. Journal of Quaternary Science 17, 101-111.

Mercer, J.H., 1976. Glacial history of southernmost South America. Quaternary Research 6, 125-166.

Morner, N., Sylwan, C., 1989. Magnetostratigraphy of the Patagonian moraine sequence at Lago Buenos Aires. Journal of South American Earth Sciences 2, 385-389.

Muller, E.H., 1960. Glacial chronology of the Laguna San Rafael area, southern Chile. Geological Society of America Bulletin 71, 2106.

Porter, S.C., 2000. Onset of neoglaciation in the Southern Hemisphere. Journal of Quaternary Science 15, 395-408.

Rabassa, J., Clapperton, C.M., 1990. Quaternary glaciations of the southern Andes. Quaternary Science Reviews 9, 153-174.

Rignot, E., Rivera, A., Casassa, G., 2003. Contribution of the Patagonia icefields of South America to global sea level rise. Science 302, 434-437.

Rivera, A., Benham, T., Casassa, G., Bamber, J., Dowdeswell, J., in press. Ice elevation and areal changes of glaciers from the North Patagonian icefield, Chile. Global and Planetary Change.

Simpson, E.M., 1875. Esploraciones hechas por la corbeta Chacbuco. Anuario Hidrografico de la Marina de Chile 1, 3-166.

Steig, E.J., et al., 1998. Synchronous climate changes in Antarctica and the North Atlantic. Science 282, 92-95.

Strelin, J., Malagnino, E., 2000. Late-glacial history of Lago Argentino, Argentina, and age of the Puerto Bandera Moraines. Quaternary Research 54, 339-347.

Sugden, D.E., John, B., 1976. Glaciers and Landscape. Edward Arnold, London.

Warren, C.R., 1993. Rapid recent fluctuations of the calving San Rafael glacier, Chilean Patagonia: climatic or non-climatic? Geografiska Annaler 75A, 111-125.

Warren, C.R., 1994. Freshwater calving and anomalous glacier oscillations: recent behaviour of Moreno and Ameghino glaciers, Patagonia. The Holocene 4, 422-429.

Warren, C.R., Aniya, M., 1999. The calving glaciers of southern South America. Global and Planetary Change 22, 59-77.

Warren, C.R., Sugden, D.E., 1993. The Patagonian icefields: a glaciological review. Arctic and Alpine Research 25, $316-331$. 
Wenzens, G., 1999. Fluctuations of outlet and valley glaciers in the southern Andes (Argentina) during the past 13,000 years. Quaternary Research 51, 238-247.

Winchester, V., Harrison, S., 1996. Recent oscillations of the San Quintin and San Rafael glaciers, Patagonian Chile. Geografiska Annaler 78A, 35-49.
Winchester, V., Harrison, S., Warren, C.R., 2001. Recent retreat of Glaciar Nef, Chilean Patagonia, dated by lichenometry and dendrochronology. Arctic Antarctic and Alpine Research 33, $247-252$. 